\title{
Comprehensive Approach in Teaching Landscape
}

\author{
Zi-Lun ZHOU ${ }^{1,2}$, Yan FENG ${ }^{1}$ \\ ${ }^{1}$ Jiangsu University of Technology, China \\ ${ }^{2}$ Philippine Normal University, Manila
}

Keywords: Discourse, Speech act, Style.

\begin{abstract}
In teaching the drama Landscape from stylistics point of view, the author of this paper employs comprehensive approach to deal with the speech act theory, the discourse analysis on the inner thoughts of the characters and the syntactic and lexical characteristics of the dialogue. The paper from five perspectives finds some stylistic features to be employed in the text analysis. Comprehensive approach in teaching and analyzing drama produces a wider horizon and deeper understanding of the text and facilitates students in appreciate the drama.
\end{abstract}

\section{General Introduction}

Landscape, a one-act play by Harold Pinter, shows the difficulties of communication between two people in a marriage. This is illustrated through the two characters who appear to be talking to one another though neither seems to hear the other. The dialogue resembles two independent monologues.

Landscape is the representative of Harold Pinter's metaphase memory play, in terms of its creative application of the traditional "Past" and "Memory". This report intends to analyze this play from the psychology of memory. In these plays, Pinter employed the vague memory to present people's fear of their inner desire, which further displayed the ubiquitous existence of menace. However, menace in this play comes from the inner desire behind human soul, instead of the outside mysterious power in his earlier plays. In the play nothing happens, the action of the play is brought to a halt, putting an added emphasis on the role of the dialogues and monologues that take place. As one critic put it "nothing happens but much is explored".

\section{Context of the Play}

According to Jonathan J. Webster (2001), context deals with (a) field: What has happened? (b)tenor: Who have participated?(c)mode: How have these happened? Pinter's one-act play Landscape is set in the kitchen of a country house. The design is minimalist in nature, consisting of a few kitchen appliances and a long kitchen table. Beth sits in an armchair to the left of the table, and Duff in a chair at the opposite end.[1]There is virtually no plot to the play. The focus is on the interaction, or lack of it, between the two characters. The text requires that "Duff refers normally to Beth but does not appear to hear her voice" and "Beth never looks at Duff and does not appear to hear his voice. Both characters are relaxed, in no sense rigid."[2] What plot there is exists only in the stories told by the characters. Beth reminisces to herself of a past romantic episode, whether with Duff or another man is not made clear. Duff talks of more practical matters, and finally has a short outburst of anger, evidently in frustration. Beth continues her romantic reverie as the play ends.[3]The author of the play indicates a somewhat new direction for the playwright. He himself puts his finger on the major change when he mentions their lack of menace. Landscape lacked physical action as well. The technique of Landscape is that of interweaving of streams of consciousness.

\section{Discourse Analysis and Inner Thoughts of the Characters}

From the beginning Duff put a positive gesture to communicate, but gradually we find that whether in reality or the recall of the past, his aim is to deconstruct the world of his wife's memory, to recover his own control. He made three attempts:

Duff: Do you remember the weather yesterday? That downfall? 
Duff in fact designed the talk to establish the true sense of the dialogue but of course has not gained Beth's response. According to the Theory of Speech Act (Austin 1962; Searle 1965,1969),(4)Duff was to offer an invitation, to require his wife to join his communication, which is a speech act but Duff failed. Thus, Duff turned to take a circuitous means of "memories" of telling their previous loving harmony. Slightly after the failure, Duff has gradually lost patience and become increasingly hesitant and anxious. According to the Co-operative Principle in conversation (Grice 1975) from the beginning to end of the play, Beth was always breaking the Cooperative Principle, especially the maxim of relation, talking about sharply different topics from Duff's.

Duff: Do you like me to talk to you?(Pause)Do you like me to tell you about all the things I have been doing? (Pause)About all the things I have been thinking? (Pause) Mmmm? (Pause)I think so.

This type of discourse brings out the psychological fear and anxiety due to the loss of Duff's power and authority. This fear ultimately barriers both husband's and wife's desire to communicate.

Beth's lines are an incantation to a past experience of love fulfilled. For her the kitchen in which she sits does not seem to exist as her wish to capture past experience brings its setting into the present and extends it into the future. Once in her life she had experienced a complete fulfillment. It is forever lost in her life with her dull husband Duff.

BETH: I would like to stand by the sea. It is there.

Pause.

I have. Many times. It's something I cared for. I've done it.

Pause. I'll stand on the beach. On the beach. Well. it was very fresh. But it was hot, in the dunes. But it was so fresh, on the shore. I loved it very much.

The three tenses used at the play's opening define time as it exists for Beth. Because she cared about her experience of love on the beach, it has become the only reality which exists for her. The sea is there for her, it was there, she wishes it to be there, and in her private world she will still stand by it.

Although in their conversation, Beth and Duff seemed to have an overlap, that is, they obeyed the Co-operative Principle, to drink in a bar, their bars are not the same and the man drinking together with Beth is not Duff but her imaginary love:

Duff: Anyway...luck was on my side for a change. By the time I got out of the park the pubs were open, so I thought I might as well pop in and have a pint...

Beth: But then I thought perhaps the hotel bar will be open. He will buy me a drink....

Beth recreates the archetypal reality of her past as a bulwark against the present reality of her husband, whom she neither sees nor hears. Against the yearningly domestic picture of her which her husband paints - that of a good housekeeper and servant and a good wife, who can forgive him his infidelities with a kiss - is her picture of herself as a beautiful, childbearing, flower-watering, adored woman —in fact, a goddess. Her removal from the daily reality that concerns her husband reinforces Beth's role as the familiar fertility goddess figure from Pinter's dramatic world, the wife-whore mother, but one who differs from his earlier heroines in her lack of inner conflict over the roles. Beth has come to accept the inevitability of her present frustrations, but she does so only by lingering on the archetypal reality of her past experience by the water.

The conflict emerges, rather, and is enriched in the attempts of Duff to make contact with Beth, attempts which fail but grow in intensity as she relives her past experience. Beth is so enthralled with the remembered light touch of her lover that the heavy-handed crudeness of Duff is unable to reach her at all. His concentration on daily existence, his walk to the pond, his discourses on the proper manufacture of beer to display his expertise and superiority, and his pride in his domestic abilities, take on something of the ridiculous in the light of her indifference and preoccupation. Duff's efforts to reach Beth, however, reveal a wistful intuition of the greater validity of her experience compared with his own. He dwells on his domestic abilities-

Duff: I could drive well, I could polish his shoes well, I earned my keep.

and likes to think they have been a good domestic "team"; but he also paints a picture of himself as isolated - unable, for example, to enter the joke of children he met or to share his wife's vision, a vision which includes children. 
BETH: The dog sat down by me. I stroked him. Through the window I could see down into the valley. I saw children in the valley. They were running through the grass. They ran up the hill.

Long Silence.

DUFF: I never saw your face. You were standing by the windows. One of those black nights. A downfall. All I could hear was the rain on the glass, smacking on the glass. You knew I'd come in but you didn't move. I stood close to you. What were you looking at?

Tension subtly increases as Duff's inability to make contact does. That tension finally erupts into Duff's fantasy of violence and rape, a fantasy ironically juxtaposed with Beth's gentle memory of fulfillment.

DUFF: I took the chain off and the thimble, the keys, the scissors slid off it and clattered down. I booted the gong down the hall. The dog came in. I thought you would come to me, I thought you would come into my arms and kiss me, even offer yourself to me. I would have had you in front of the dog, like a man, in the hall, on the stone, banging the gong, mind you don't get the scissors up your arse, or the thimble, don't worry, I'll throw them for the dog to chase, the thimble will keep the dog happy, he'll play with it with his paws, you'll plead with me like a woman, I'll bang the gong on the floor, if the sound is too flat, lacks, resonance, I'll hang it back on its hook, bang you against it swinging, gonging, waking the place up, calling them all for dinner, lunch is up, bring out the bacon, bang your lovely head, mind the dog doesn't swallow the thimble, slam-

BETH: He lay above me and looked down at me. He supported my shoulder.

Pause.

So tender his touch on my neck. So softly his kiss on my cheek.

The final counterpoint of fantasy in rape (Duff) and love fulfilled (Beth) remains dramatic as Duff's anger reflects his failure to make contact, and Beth's sense of transcendent, mythical time makes her isolation, paradoxically, a connection. Rather than an archetypal reality emerging into the daily lives of the people, all remains muted, essentially unexpressed, contained only in the fantasies of the characters. For Duff, frustration passionately felt, for Beth reality only in a dream.

\section{Different Love Landscape of the Characters}

The monologue between the two people brought us into their memory of very different landscape of love. Beth's memory world is full of fantasy scenes full of romantic atmosphere, together with her lover in a romantic seaside .Quiet and isolated beach, with sands and fresh air is the right place the women in love desire. At the time, her man is lying on the sand dunes,

Beth: his eyelids, belly button, Snoozing how lovely.

Bits and pieces of description are all revealing her love for this man. Although she stressed that she was lying down by his side, no contact took place. But she wanted to have their own children, and under the white bathrobe is her naked body again is all revealing Beth's expression of her deep love for the man.

From Beth's memory of landscape, we see her longing for love, and her emotional appeal with her love is calling, "Oh, my true love!" Compared with Beth's memories of love filled with infinite tenderness , Duff's memory world is nothing but trivial events in daily life, no emotional events. In the beginning, Duff was constantly telling about his going somewhere yesterday, the dog was lost, park, heavy rain after heavy rain, the pond, a man's and a woman's sheltering from the rain by the pond and so on. Even when dating back to the old memories, he provided us with no more than the information about the two of them. They are servants of the owner of the house of Sykes, the two are a good pair. Duff may be a good car driver, a good rubber for master's shoes, and Beth is a first-class housewife, who organized and managed master's house orderly. In addition to the memories of the chores of life and memories of his personal emotions almost unpleasant, the memories are of his betrayal to Beth to whom he told the truth and from whom he seeks the forgiveness. He showed his hatred to his house master. That hatred comes from the house owner's special treatment to Beth. Even though he believes the owner let Beth wear good clothes in front of the guests in order to look decent. He is constantly telling more and more but this reflected his efforts to have communication with her are a failure and a great deal of frustration, and the last memories of this frustration nearly let him employ barbaric violence to vent his grievances.

Lying beside her lover at the beach, Beth reemphasized "no contact", highlighting Beth's desire to touch the lover or to be touched by the lover. In seawater, she is feeling the delicate and gentle waves and 
imaging lover's gentle touching her back; she seems to have a little confusing memory fragments of watering the flowers, as if "he" is Duff or her lover is at the seaside. However, we can not get to the bottom to figure out who is that "he" in the end, whoever he is does not seem so important and what matters most is that in the memory, Beth is feelings she is not watering the flowers, but feels that he is close to her, offering her gentle tender touch, which is Beth's interpretation of love and comfort of the human mind. Lover took her to a desolate seaside better for her is her to have painting, but for Duff, Beth is only a housekeeper, a pattern of life. But for her, the lover is the picture that she wanted to depict .Duff is to find a suitable life partner. For him, Beth is the class-class housewife, who always manages the room orderly, of which he was very proud of. Duff's entire memory is focusing on a specific transaction, but is lack of perception of love. It seems that we can not see his gentle love for Beth. If there is any, it is that he confessed to his own betrayal to Beth.

Duff:I told you that I let you down, I had been unfaithful to you. Duff's rare tenderness is just to make a compensation for his guilt. In addition to the lack of tender love, sex also has two sharply different interpretation and disparate understanding in the eyes of Beth and Duff. Although love is leading to the ultimate sex performance, for Beth as woman, sex is the expression of emotions, the desire, but it is due to the emotion of desire or lust. Duff, as a man, also has the desire for his lover, and this desire is sexual desire. On a dark rainy night, Beth is standing by the window, caught in an illusion, and Duff is standing close to her,

Duff: Without touching you, I could feel your bottom.

This undoubtedly is a naked expression of sexuality. For last imagination of rape, perhaps just an imagination, we do not see any love, but merely sex, a retaliation for the fact that Beth refuses to communicate with him, meanwhile, as a male playwright, through Landscape, the author is trying to convey such a message to us , that communication gap caused by the difference of sexes is not a deliberate result, and in such a groove, while the man is making all sorts of efforts not based on a true understanding of a woman, it will inevitably lead to a failure to communicate.

\section{Text Analysis}

According to Jan Renkema's Discourse Studies (1993), seven standards can serve to judge if sequences of sentences can be text:1.Cohesion2. Coherence3. Intentionality4. Acceptability5. Informativeness6. Situationality7. Intertextuality. Halliday and Hasan hold that cohesion consists of five factors: reference, substitution, ellipsis, conjunction, lexical cohesion to form a text.

Beth: I drew a face in the sand, then a body. The body of a woman. Then a body of a man, closing to her, not touching. But they did not look like anything. I crept close to him and put my head on his arm.

"Her" is a reference, referring to the woman, while "they" refer to the man and the woman, "him" refers to the man, and "his" refers to the man.

Beth: I would like to stand by the sea. It is there.(Pause)I have. Many times. It is something I cared for. I have done it. (Pause) Lots of people. (Pause)He turned over as I stood. His eyeslides. Belly botton. Snoozing how lovely. (Pause)Would you like a baby? I said. Children? Babies? Of our own? Would be nice.

In fact the above conversation filled with reference, substitution, ellipsis, conjunction may be paraphrased as the following:

Beth: I would like to stand by the sea. It (reference of The sea)is there(substitute of a definite or specific place).(Pause)I have (ellipsis of stood by the sea)(ellipsis offor) many times. It(reference of to stand by the sea) is something (ellipsis of that)I cared for. I have done(proverb of stood) it(reference of have stood by the sea). (Pause)Lots of people (ellipsis of are by the sea). (Pause)He turned over as (temporal conjunction) I stood. His eye slides and Belly button (ellipsis of are attracting me) (ellipsis of he is) snoozing. How lovely (ellipsis of it is to be with him on the beach)! (Pause)Would you like a baby? I said. (Would you like to have)Children, (Would you like to have)Babies(substitute for children)? (ellipsis of would you like to have)Of our own? (ellipsis of It) Would be nice.

In fact we may find some examples of anaphora of different kinds in the conversation: 
Duff: Do you like me to talk to you?(Pause)Do you like me to tell you about all the things I have been doing? (Pause)About all the things (noun anaphora) I have been thinking? (Pause) Mmmm? (Pause)I think so (anaphora).

Duff: Mr.Sykes took to us from the very first interview, did'n't he (pronominal anaphora)?

Duff: He trusted you to run his house, to keep the house to the mark, (he has zero-anaphora)no panic.

In anaphora, as opposed to cataphora, reference is made based on preceding parts of the utterance.

Beth: My man slept in the dune. He turned over as I stood

\section{Conclusion}

Teaching literature in a comprehensive approach is to appreciate the whole things in the literature works. This paper explores the drama from the perspective of speech act theory, text analysis, stylistics, figure of speech and psychology to find the characters in the drama living in a unique way. The wife and the husband fall into a motional crisis and they do not love each other anymore. What is more, they do not share the same concept of love, which is proved by their conversation in which answers have nothing to do with the questions, the title of the drama Landscape is the symbol of love which the couple encode in different way. The unique perspectives Pinter employs to dig the inner thoughts of the characters are the best channel for teaching drama and facilitate readers to appreciate the drama in a fantastic way, which forms the writing style of the author of the drama.

\section{Reference}

[1] http://en.wikipedia.org/wiki/Landscape_(play)

[2] http://en.wikipedia.org/wiki/Landscape_(play)

[3] http://en.wikipedia.org/wiki/Landscape_(play)

[4] Mick Short, Discourse Analysis and the Analysis of Drama, The stylistics Reader, from Roman Jakobson to the present Edited by Jean Jaques Weber, University Centre Luxebourg.

[5] The Guardian 11 January 2008.

[6] Information on http://www.ohiostatepress.org/books/Complete\%20PDFs/Burkman\%20Dr. 